\title{
ФИЗИЧЕСКАЯ АНТРОПОЛОГИЯ
}

\section{МИГРАЦИОННЫЕ ПОТОКИ ИЗ АПЕННИНСКОГО ПОЛУОСТРОВА В КРЫМ (КОНЕЦ ХVIII - НАЧАЛО ХХ ВЕКА)*}

В статье рассказывается об истории группы итальянцев Крыма. История группы до сих пор мало изучена и богата мифами и легендами. Проведенное комплексное историко-антропологическое, генетическое исследование общины позволило развеять данные мифы, которые укоренились среди представителей общины и за ее пределами, а также позволило воссоздать историю миграчий, их географию и причины. Историческая часть исследования основана на изучении источников и документов, найденных в российских и итальянских архивах. Была проведена работа с документами из Государственного архива Саратовской области ГАСО, из государственного архива Республики Крым, из Российского государственного военного архива РГВА г. Москва, в государственных архивах г. Генуя, г. Неаполь, г. Бари, г. Турина, в Ватиканском секретном архиве. Не менее ценнная и обширная информация была найдена в газетных и иными периодических изданий XIX-XX вв., хранившихся в российских и итальянских библиотечных фондах. Важное место также занимает работа с материалами из семейных архивов потомков итальянских мигрантов. Часть найденных материалов представлена в этой статье.

Особое место в статье занимает проблема численности общины, которая сегодня, как и в прошлом, трудно определима.

Ключевые слова: миграционные потоки, мигранты, исторический очерк, полевые исследования, Крылские итальянщы, Керчь, Апеннинский полуостров, Италия, Крьмм

Дзини Стефания - соискатель ученой степени к.и.н. Института этнологии и антропологии РАН (Москва, Ленинский пр. 32А). Председатель комиссии этнографии, антропологии и археологии МГО РГО (Новая площадь, д. 10, стр. 2). Эл. почта: stefania.zini@mail.ru. Stefania Zini $\mathrm{PhD}$ candidate in historical sciences at the Institute of Ethnology and Anthropology of the Russian Academy of Sciences (Moscow, Leninskii pr. 32A). E-mail: stefania.zini@mail.ru

Хохлов Никита Викторович - научный сотрудник Института этнологии и антропологии РАН (Москва, Ленинский пр. 32А). Ученый секретарь комиссии этнографии, антропологии и археологии МГО РГО (Новая площадь, д. 10, стр. 2). Эл. почта: ethno@yandex.ru. Nikita V. Khokhlov - Institute of Ethnology and Anthropology of the Russian Academy of Sciences (Moscow, Leninskii pr. 32A). E-mail: ethno@yandex.ru

* Публикуется в соответствии с планом научно-исследовательских работ Института этнологии и антропологии РАН 


\section{Предисловие}

Попытка реконструировать историю последних, самых поздних миграций населения Апеннинского полуострова в Крым ${ }^{1}$, является частью комплексного исторического, антропологического и демографического исследования современного итальянского населения Крыма.

Речь идёт о небольшой группе индивидов итальянского происхождения, являющихся потомками итальянцев ${ }^{2}$, мигрировавших из различных регионов итальянского полуострова в Крым и в другие города Черноморского и Азовского побережий, разными миграционными потоками в течение чуть больше столетия, начиная с начала XIX века до начала XX века.

1 В тексте используется название «Крым» для географического обозначения Крымского полуострова вне зависимости от исторических эпох повествования, учитывая, что в разное время данная территория имела разные названия.

После присоединения Крымского полуострова к Российской Империи в 1783 году, название Крым, которое впервые встречается в XIII веке, продолжается использоваться в официальных документах, в то же время полуостров называют Тавридой. В этой же эпохе, Таврией - от старого названия Таврика, Таврия-страна тавров - называют прилегающие с севера к Крыму плодородные земли Таврической Губернии.

Таврическая Губерния, как административно-территориальная единица, образуется в 1802 году указом Александра I, в результате разделения Новороссийской губернии и состоит из 7 уездов Днепровский, Евпа-торийский, Мелитопольский, Перекопский, Симферопольский, Тмутараканский, Феодосийский.

В 1820 году Тмутараканский уезд был передан в Кавказскую губернию, в 1838 году из Симферопольского уезда выделен Ялтинский уезд, а Днепровский и Мелитопольский уезды разделены на 3 уезда: Бердянский, Днепровский и Мелитопольский в 1842 году.

Центром Таврической губернии - г. Симферополь.

В составе губернии в разное время существовали градоначальства: Феодосийское (1804-29), КерчьЕни-кальское (1821-1917), Севастопольское (1873-1917, 1919-1920), Ялтинское (1914-1917).

С 1804 гл. рос. воен. портом на Чёрном м. стал Севастополь.

В 1917-1918 гг. в Таврической губернии была установлена советская власть.

Потерпев многочисленные территориальные изменения согласно постановлению ВЦИК от 18.10.1921, крымские уезды бывшей Таврической губернии составили Крымскую АССР в составе РСФСР.

${ }^{2}$ В тексте используются слова «итальянцы» и «Италия» не только в современном понятии жителей страны, получившей данное название в 1946 году, после проведения национального конституционного референдума.

Если контекст не требует точного обозначения одного или иного из существующих в XVIII-XIX вв. на Апеннинском полуострове государств, со словом «Италия» будем означать совокупность государственных образований, занимающих полуостров до их объединения в Итальянское Королевство в 1861 году. Итальянцами будем называть всех мигрантов из Апеннинского полуострова, независимо от государств принадлежности, существующих до объединения Италии.

Хотя этимология слова «Италия» до сих пор не определена - существуют многочисленные гипотезы - известно, что данное название имеет давнюю историю.

Согласно Страбону, о границах «Италии» говорил Антиох Сиракузский еще в V веке до н.э. в своей работе «Об Италии», где «Италия» означало только часть полуострова, сегодняшний регион Калабрия.

С времен римских завоеваний, слово Италия стало означать более обширную территорию, включая Альпы и Лигурию, а жители полуострова назывались италиками или римлянами.

Этимология слова «италики», с которого происходит слово «итальянцы», также неоднозначна. Согласно одной из гипотез данное название имеет очень старое происхождение: древние греки называли «Itali» жителей, проживающих в центральной и южной части региона Калабрии. 
Численность данной группы на сегодняшний день трудно определима, так как и представители старших поколений, являющиеся прямыми потомками коренных итальянских предков, и их дети, внуки и правнуки, все рождённые в смешанных браках, давно лишились итальянского подданства и гражданства. Добровольно или вынужденно отказавшись от родного гражданства, в разное время они приняли подданство Российской Империи, стали гражданами Советского Союза, Украины, Российской Федерации ${ }^{1}$

Определить численность группы по языковому принципу или по вероисповеданию, как было принято в прошлом, например, в Памятных книжках Российской Империи, также сегодня невозможно. Среди членов группы итальянский язык и католическая вера были полностью утрачены в Советскую эпоху и вновь приобретены в единичных случаях только с недавнего времени ${ }^{2}$. Провести учёт современного итальянского населения Крыма по исконным фамилиям не даст объективных результатов. Чаще всего, итальянские фамилии терялись в процессе смешения, были забыты или изменены до неузнаваемости.

По данным Переписи населения в Крымском федеральном округе, которая проводилась в 2014 году, 77 человек назвало себя итальянцами (Итоги переписи населения в Крымском Федеральном округе 2015: 143).

В ходе экспедиций, проведённых нами в Крыму в 2016-2018 гг. было опрошено 131 человек (53 мужского пола, 78 женского пола), которые считают себя этническими итальянцами. Если довериться сведениям неофициальных переписей, регулярно проводимых самыми активными членами группы, численность итальянцев Крыма совсем другая (Карта № 1). ${ }^{3}$

Данные по численности общины, собранные её членами, имеют уникальный характер (График №1) ${ }^{4}$. Это единственная форма учёта количества крымских итальянцев, проживающих сегодня не только в Крыму, но и за её пределами. Ведь, вследствие частых и масштабных исторических перемен, произошедших со дня возникновения общины, в частности в первой половины XX века, часть крымско-итальянского населения расселилась в разных регионах и городах РФ, Италии и мира.

${ }^{1}$ Неопубликованные демографические опросы, проведенные в ходе экспедицией в Крыму 2016-2018гг., Саратове 2017г., Московской области, в Москве. Опрошено всего 131 человек (53 мужского пола, 78 женского пола).

Собрана информация демографического характера до четвертого поколения, на основании которой можно отметить, что массивный процесс метисации крымских итальянцев с другими этническими группами, с русскими, украинцами, татарами, караимами, казахами и др. заметно усилился с начала XX века. Это - также повлияло на потерю или отказ от родного гражданства.

2 По неопубликованным демографическим опросам [см.3.] на сегодняшний день, среди 131 опрошенных, 7 владеют итальянским языком, недавно приобретенным, на разговорном или выше уровне. Средний возраст итальянско-говорящих - 33 года.

Среди крымских итальянцев, сегодня исповедают католическую веру 15 опрошенных. Большинство отмечает католические праздники, хотя называют себя православными.

${ }^{3}$ Карта № 1 составлена по данным из личных архивов Джулии Джаккетти-Бойко (г. Керчь) и Петр Пергало (г. Санкт-Петербург)

${ }^{4}$ По неопубликованным демографическим опросам [см.3.] на сегодняшний день, среди 131 опрошенных, 7 владеют итальянским языком, недавно приобретенным, на разговорном или выше уровне. Средний возраст итальянско-говорящих - 33 года.

Среди крымских итальянцев, сегодня исповедают католическую веру 15 опрошенных. Большинство отмечает католические праздники, хотя называют себя православными. 


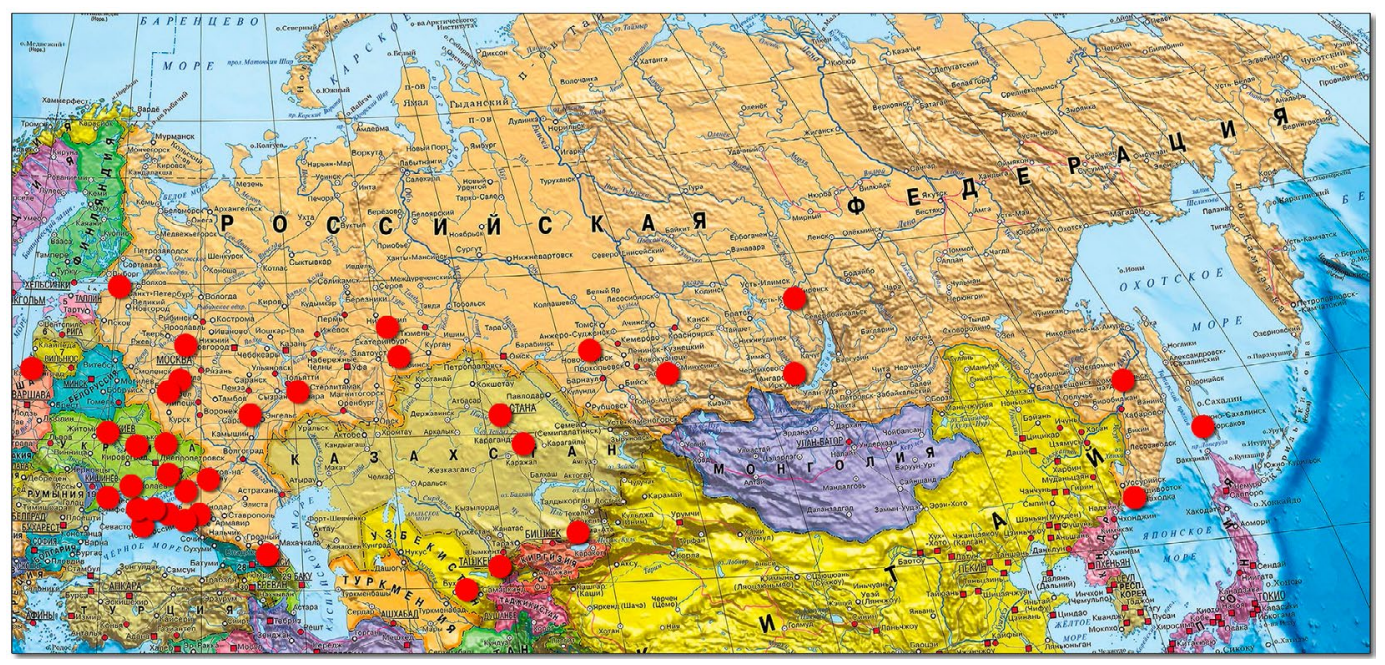

Puc. 1. Kapma №1.

Карта расселения потомков крымских итальянщев на сегодняшний день.

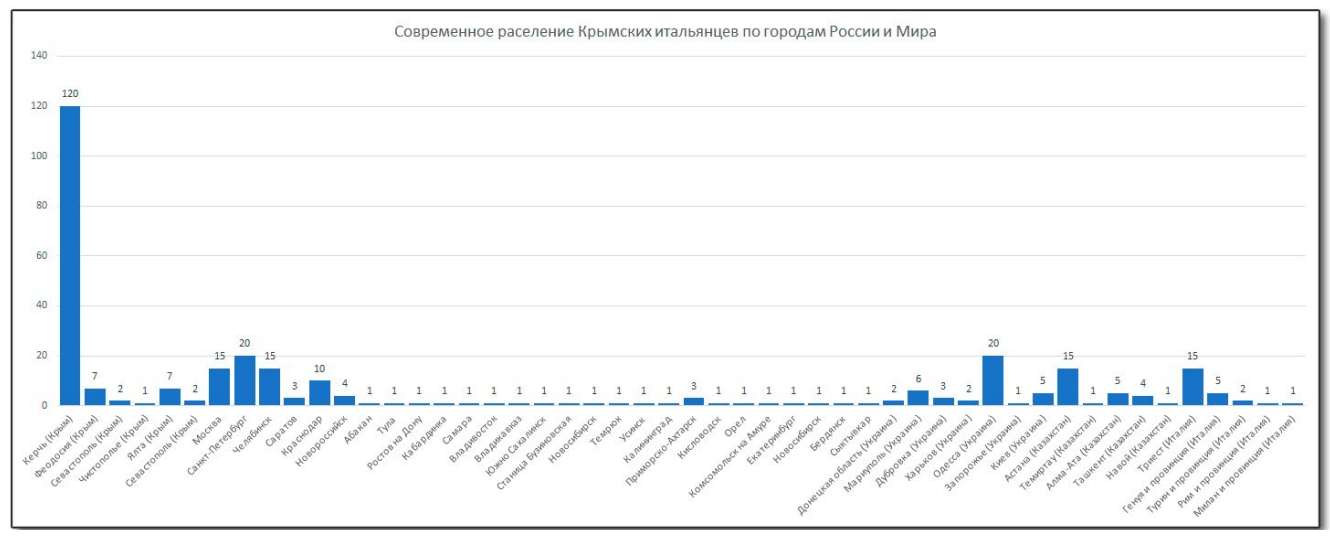

Рис. 2. График № 1. На графике представлено количественное расселение Крымских итальянцев по городам России и Мира.

Поэтому, в рамках нашего исследования, основанного, в частности, на работе с живым населением, мы будем пользоваться данными неофициальной, внутригрупповой переписи, заранее учитывая вероятность погрешности собранных сведений. С одной стороны, это - единственный источник постоянно обновляемой информации и он имеет, поэтому бесспорную ценность. С другой стороны, работа, сделанная на энтузиазме и в частном порядке, часто проводится при отсутствии исторических сведений, из-за их объективной труднодоступности. Редко материалы из семейных архивов, играющие важную роль в данном виде учёта, имеют исчерпывающий характер и могут удовлетворительно дополнить или подтвердить фрагментарные воспоминания потомков итальянцев, которые могли бы оказаться в России вследствие других миграционных потоков и не принадлежащих к интересующей нам группе.

Ещё одно обстоятельство, не менее важное - внутригрупповая форма переписи грешит субъективностью и эмоциональностью, так как основывается на этническом самосознании каждого возможного члена группы. Очевидно, желание принадлежать 
к одной или другой этнической группе слабеет или усиливается в каждом индивиде в разных исторических эпохах, в непосредственной зависимости от степени культурного, социального, политического или иного вида выгоды или необходимости. Случай с итальянским населением Крыма, это - очень яркий пример.

На данном этапе нашего изложения, не будем учитывать все трудности и превратности, пережитые итальянскими переселенцами, влияющие на этническое самосознание мигрантов в сложном и переменчивом XIX-м веке, до и после миграции. Будем рассматривать два примера, показывающих полярно противоположное желание итальянских мигрантов и их потомков быть или не быть зачисленными в итальянское население Крыма.

В 20-40 годы XX века, дабы избежать неприятности и обезопасить себя, большинство итальянских мигрантов и их потомков, тщательно скрывали и отрицали свои корни, меняя фамилии, порою кардинально, принимая другую веру, сознательно забывая родной язык и, запретив на нем разговаривать близким и родным, этим способствуя собственной русификации. С недавнего времени, отмечается обратный процесс.

Указом Президента РФ от 12 сентября 2015 г. № 458 «О внесение изменений в Указ Президента РФ от 21 апреля 2014 г. № 268 «О мерах по реабилитации армянского, болгарского, греческого, крымско-татарского и немецкого народов государственной поддержке их возрождения и развития», (http://kremlin.ru /acts/bank/38356 2015) итальянцы официально добавлены в список малочисленных народов Крыма, репрессированных советским режимом, депортированных и, наконец, также как представители других народов, имеют права на реабилитацию. С этого момента, численность итальянского населения Крыма заметно возрастает.

Наше решение уделить особое внимание вопросу численности современного итальянского населения Крыма в самом начале нашего повествования, носит скорее провокационный характер так, как сразу поднимает более принципиальную проблему. С какого момента, с какого итальянского мигранта имеем мы право начать вести исторический учёт так называемых “Итальянцев Крыма”? Кого из мигрантов включить в динамику возникновения и развития группы? Только тех, кто с Апеннинского полуострова мигрировал сразу в Крым или многих других, для которых Крым, как доказывают источники, стал второй или третей остановкой в их кочевании по городам Черноморского и Азовского побережий?

Их называют, они себя называют, “крымскими Итальянцами” или сужая географическое понятие формирования группы, “итальянской керченской общиной” или просто «керченской группой”. Имеют ли последние два названия право на существование, возникает острый вопрос. Они отражают сегодняшнее географическое сосредоточение группы, в то же время, применяя эти названия, меняется перспектива в определении миграционных путей. Понятие «керченской группы» или «керченской общины» предполагает образование и существование отдельной группы итальянских мигрантов, истории которых не имели и не имеют никакого отношения к судьбам итальянских мигрантов, поселившихся в других городах Крыма и черноморского-азовского побережий. Данное понятие, широко распространилось среди краеведов и историков (Шишмарев 1975: 165) и укоренилась среди современных итальянцев Крыма, для которых защищать статус обособленной группы является принципиальным. 
Знакомившись с историей крымских итальянцев из уст представителей общины, мы интуитивно усомнились в существование отдельной “керченской группы” и это стало отправной точкой нашей многолетней исследовательской работы, которая, если развеяла далеко не все тайны и сомнения, связанные с миграциями итальянцев в Крым и на черноморские и азовские берега, но все же пролила свет на некоторые важные вопросы.

Сегодня, мы имеем право сказать, что “керченской группы”, как настоящей обособленной единицы, не было или - если все-таки принимая такое понятие, широко вошедшее в обиход - можно допустить, что группа состояла из небольшого количества семей. Мы пришли к выводу, что существование многочисленной «керченской общины», как результат отдельного миграционного потока, это - один из многих созданных или возникших «мифов», связанных с процессом возникновения и развития нашей группы.

Ниже приведем несколько примеров, которые отражают, как судьбы некоторых итальянских мигрантов или целых семейств, традиционно относящихся к итальянской общине г. Керчь, были не менее тесно связанны с другими городами черноморского и азовского бассейнов.

\section{Пример 1}

Известной в г. Керчь личности, итальянскому дипломату и коммерсанту Рафаэлю Скасси, прибывшему в Керчь в 1832 году, приписывается возрождение Керчи, строительство керченского морского порта и водозабора (так называемого «Скассиев фонтан»). Он так же был организатором первых регулярных и масштабных археологических экспедиций, владел в Керчи лучшим фруктовым садом в Империи.

Несколько лет раньше, жизнь Скасси была тесно связана с Феодосией. Рафаэль Скасси был Conselleir du Cour в феодосийской масонской ложе Иордана (Loge du Jourdan), со дня создания в 1812 году и до дня закрытия в 1822 году (Фото № 1) (Список членов Феодосийской масонской ложи Иордана 1812: 95)

\section{Пример 2}

Судьба итальянского семейства Лагорио связана с Крымом с начала XIX века и до начала XX. C 1812 года Феликс и Джованни (Иван - Jean) Лагорио, также как и Рафаэль Скасси, состояли в феодосийской масонской ложе Иордана (Фото № 1).

По данным Памятных Книжек Керчь-Еникальского градоначальства 1860, 1863 1865 гг., сын Ивана Лагорио, Александр Иванович Лагорио, служил коллежским асессором в коммерческом суде, в Министерстве юстиции г. Керчь (Памятная книжка Керчь-Еникольского Градоначальства 1860: 21).

Внук Ивана Лагорио, Лагорио Евгений Александрович, служил при Министерстве народного просвещения г. Керчи, учителем математики в Александровской гимназии (Памятная книжка Керчь-Еникольского Градоначальства 1865: 20).

А уже в 1906 году, представитель семейства, Георгий Иосифович Лагорио, по данным Памятной Книжки Керчь-Еникальского Градоначальства, числился начальником Крепостного коммерческого управления г.Керчи (Памятная книжка Керчь-Еникольского Градоначальства 1906: 12). 


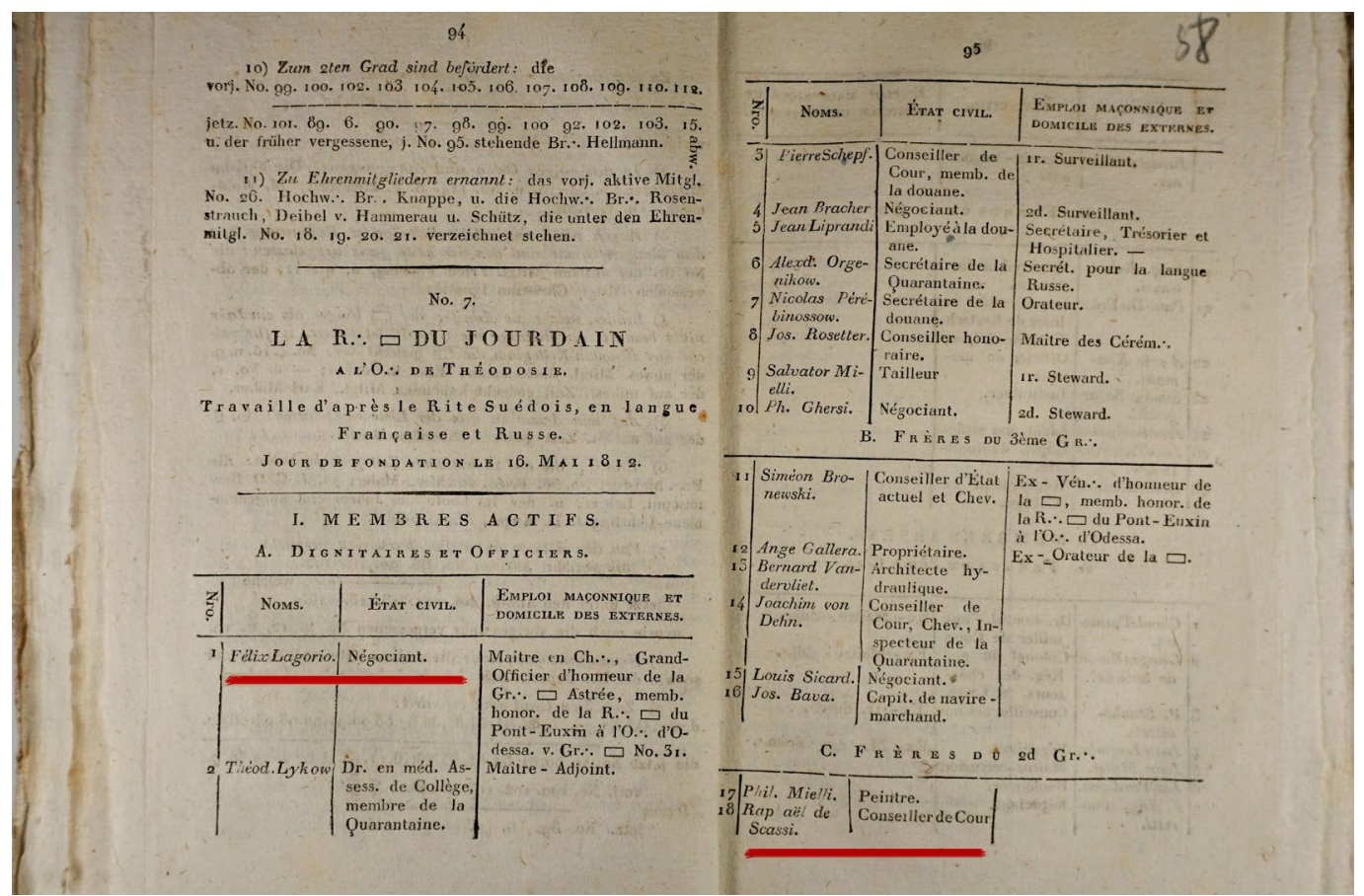

Puc. 3. Фото № 1 (РГВА. Ф. 730К. On.1. Д. 229).

\section{Пример 3}

Фамилию Томазини, мы находим в г. Одесса, в 1835 году. О чем имеется запись в метрической книге римско-католических церквей херсонского деканата о родившихся в 1834-1835 гг. - Государственный архив Саратовской области ГАСО.

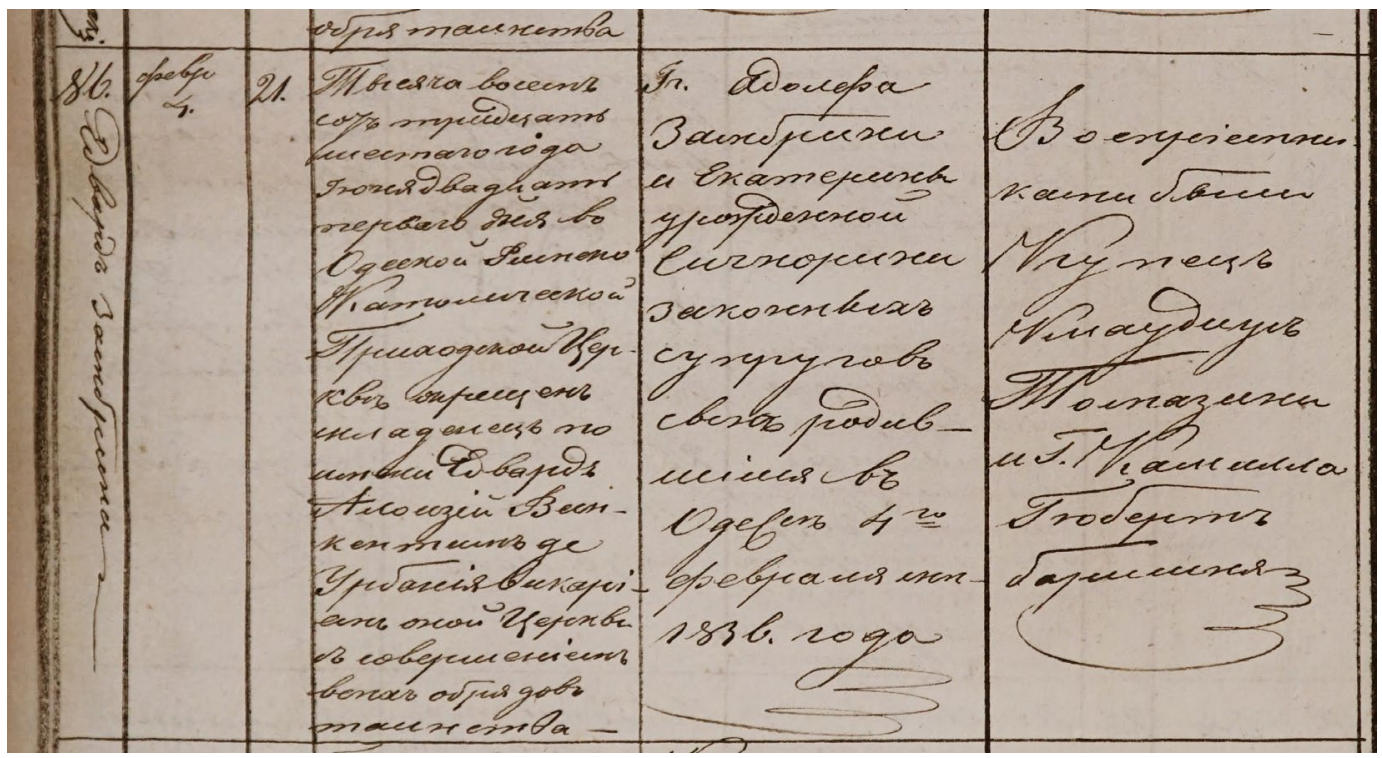

Pис.4. Фото № 2. Одесса 1836 г., Купец Клаудиус Томазини восприемник при крещении ребенка (Метрическая книга римско-католических ичерквей херсонского деканата о родившихся в 1834-1836 г2. ГАСО). 
В 60-х годах XIX века, разные члены семьи Томазини занимают важные должности Керченского Градоначальства - 1-ый гильдии купец Иван Семенович Томазини был непременным членом строительного комитета, а в коммерческом суде при Министерстве Юстиции - был членом от купечества. (Памятная Книжка Керчь-Еникальского градоначальства 1860: 15, 20-21) В 1902 по данным из Памятной Книжки по Таврической губернии (издание Таврического губернского статистического комитета), Юлий Иванович Томазини работал в тюремном комитете г. Керчь (Памятная Книжка Таврической губернии 1902: 179).

Условно «мифами» об истории крымских итальянцев, мы решили назвать весь ряд не всегда документально подкреплённых истин, ставших аксиомами среди исследователей и, заимствованными современными итальянцами Крыма (или наоборот). Дабы оправдать нашу точку зрения, которая не всегда сходится со мнением авторитетных учёных, приведём ниже несколько примеров, с надеждой показать, как полное или частичное несоответствие, противоречивость сведений, может порождать новые взгляды на историю общины.

Известный русский-советский филолог-романист В.Ф. Шишмарев, в своём труде «Романские поселения на юге России» утверждает: «Керченская группа существовала ещё до 40-х годов XIX в.; в эти годы в Керчи имелся специальный сардинский вице-консул (Раффаэле Кикизола), что даёт основание заключить, что группа была достаточно велика...». (Шишмарев 1975: 165)

\section{Наши комментарии:}

«Группа, достаточно велика...» - понятие растяжимое. К тому же, можно предположить, что присутствие в те годы сардинского вице-консула в Керчи было больше связано с нарастающей важностью коммерческих и торговых сношений между Сардинским Королевством и городами Черноморского и Азовского побережий и с увеличением количества временно пребывающих в Керчь сардинских мореходцев, нежели с заметным прибавлением постоянно проживающих граждан Сардинского Королевства. 
До начала XX века Статистический комитет г. Керчь не имел сведения о постоянно меняющихся пришлых рабочих людей, из-за отсутствия в Керчи учёта приезжающих и уезжающих. (Памятная книжка Керчь-Еникальского Градоначальства. 1900: 56)

30-40-е годы XIX века - было как раз то время, когда роль Керченской таможенной и пограничной стражи и керченского карантина, в рамках морской торговли регионального и международного уровня, становится все важнее и важнее.

В 1834 году Таганрогский карантин и Мариупольская, Бердянская и Еникальская заставы уничтожаются. В 1837 году, с упразднением Феодосийского Градоначальства, карантинная и таможенная части города подчиняются г. Керчь, а в 1838 году всем судам, идущим из Азовского моря постановлено заходить в г. Керчь для получения карантинного свидетельства. (Памятная книжка Керчь-Еникальского Градоначальства. 1860: 67-70)

Приток иностранного, в том числе итальянского элемента в г. Керчь, вследствие указанных обстоятельств, вероятно увеличивался, но прибавляется ли заметно количество проживающих в Керчи итальянцев. В этом заставляют усомниться характеристики римско-католического костёла Успения Богородицы, построенного в $1831-1840$ гг.

Имея небольшую площадь и учитывая, что в католических церквях установлены скамьи, на которых верующие сидят во время части богослужения, можно думать, что собор был рассчитан на небольшое количество посетителей - не более чем 120 чел.

К католикам Керчи нужно отнести не только уроженцев Апеннинского полуострова традиционно набожных, но и французов, немцев, поляков, австрийцев, чехов и др. Также вероятно, костёл посещала часть огромного количества иностранных мореходцев католического вероисповедания, временно пребывающих в городе, что позволяет предположить, что постоянная проживающая в Керчи итальянская община не могла быть большой.

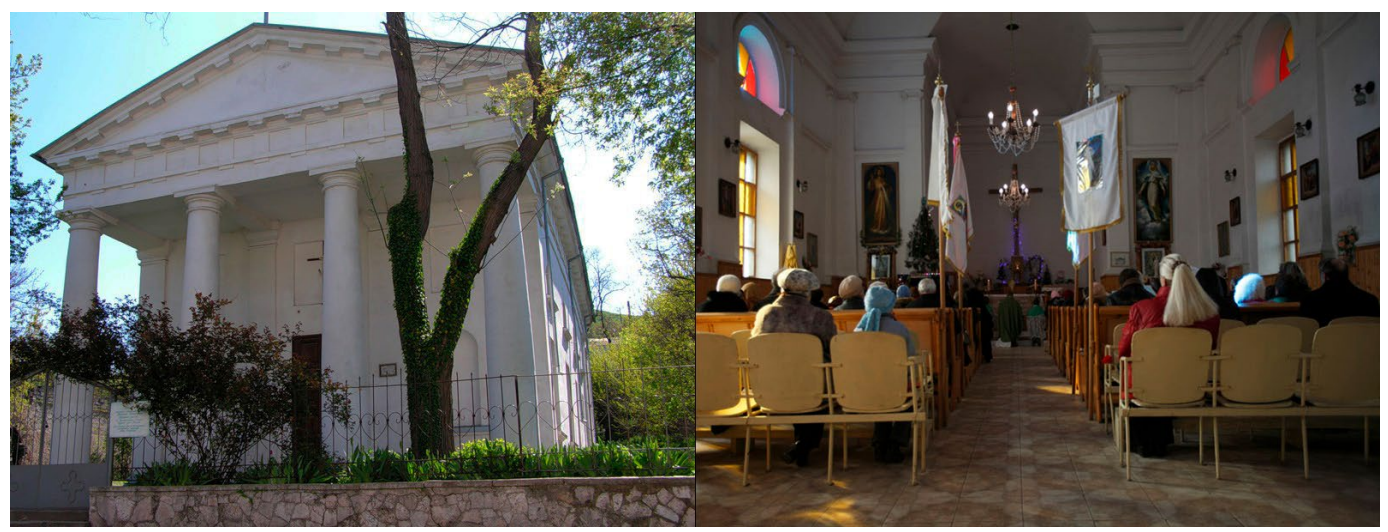

Рис.6. Фото № 4. Римско-католическая иерковь Успения Пресвятой Девы Марии2. Керчь

Далее, Шишмарев говорит об увеличении притока итальянцев в Керчь в 60-е годы XIX века, в особенности в 1862-1865 и 1869 гг. Наоборот, в 70-е годы исследователь отмечает уменьшение прилива мигрантов до полного сокращения в 80-е годы. (Шиимарев 1975: 165) Джулия Джаккетти-Бойко, глава итальянской общины Крыма, в своём труде «Итальянцы Крыма - История и судьбы» пишет, что не менее тысячи 
(а по некоторым данным до 5 тысячи) итальянцев из региона Апулия переехало в Керчь во второй половине XIX века (Джаккетти-Бойко 2016: 71).

\section{Наши комментарии:}

Статистические данные из Памятных Книжек Керчь-Еникальского градоначальства за 1857-1864 гг. о количестве жителей градоначальства по вероисповеданию, подсказывают, что итальянское присутствие было небольшим.

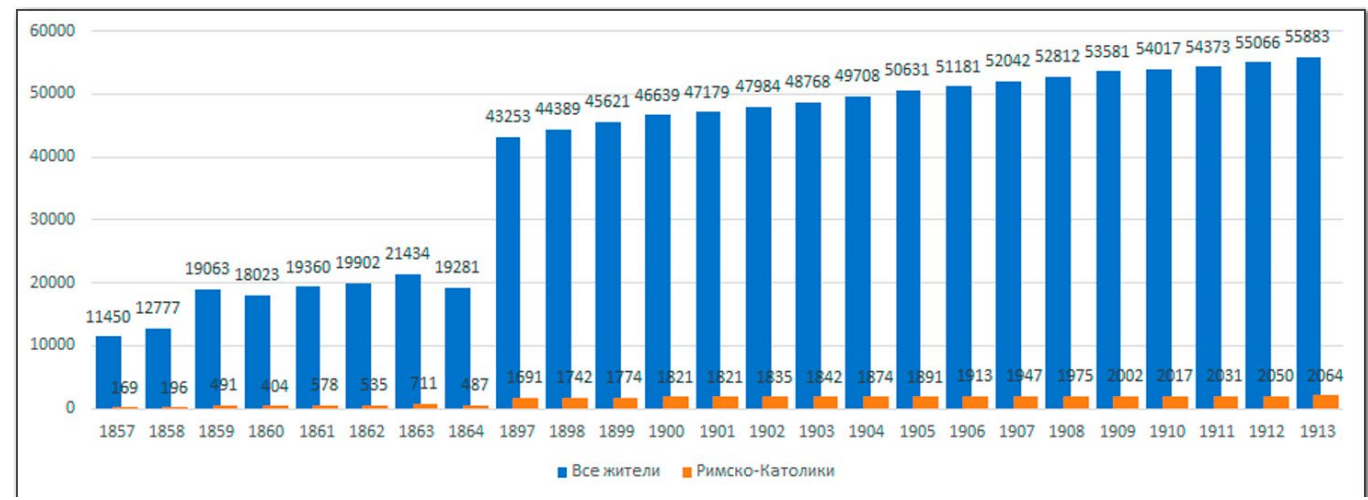

Рис.7. График № 2. Количество жителей римско-католического вероисповедания, проживающих в Керчь-Еникальском градоначальстве в 1857-1865 г2. и 1897-1913 г2. в сравнении с общем количеством жителей г. Керчь. Статистические данные из Памятных Книжек Керчь-Еникальского градоначальства за 1857-1864 г2., 18971913 гг. (Памятные Книжки Керчь-Еникальского градоначальства 1857-1864;

$$
\text { 1897-1913). }
$$

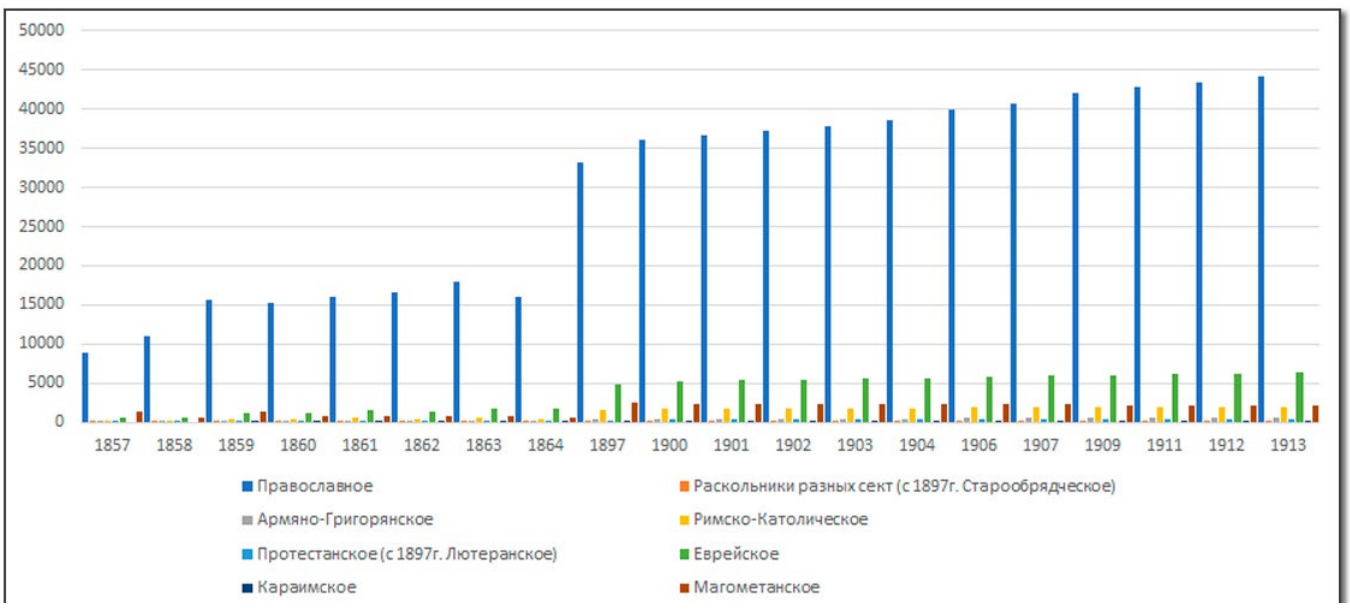

Рис.8. График № 3. Число жителей по вероисповеданию проживающих в КерчьЕникальском градоначальстве в 1857-1865 г2. и 1897-1913 г2. в сравнении с общем количеством жителей г. Керчь. Статистические данные из Памятных Книжек Керчь-Еникальского градоначальства за 1857-1864 г2., 1897-1913 г2. (Памятные Книжки Керчь-Еникальского градоначальства 1857-1864; 1897-1913) 


\section{Важно отметить, следующее:}

- в число жителей римско-католического вероисповедания нужно в этом случае, причислить не только итальянцев, но и жителей других национальностей, исповедующих католицизм;

- в трудах Шишмарева и Джаккетти речь идёт об итальянском населении города Керчь, в Памятных Книжках о населении всего Керчь-Еникальского Градоначальства. В Градоначальстве римско-католический костёл в то время был один, в г. Керчь, его посещали католики, проживающие за пределами города, что потенциально ещё больше уменьшает величину городской итальянской общины;

- 1863 год, в рамках данного временного диапазона, является кульминационным по количеству католиков, что совпадает с тенденцией к увеличению притока итальянцев, выявленной Шишмаревым, но в 1864 году заметный спад не соответствует мнению учёного.

- мы также решили выделить 1897 год так, как заметное увеличение количества католиков в Градоначальстве соответствует данным Джаккетти, в то же время также отрицает тенденцию, описанную Шишмаревым.

Можно предположить, что большинство итальянских мигрантов, являющихся объектом нашего исследования, придерживалось римско-католического вероисповедания и активно участвовало в богослужении. С другой стороны, мы находим свидетельства о мигрантах изучаемой группы в документах из иных мест богослужения. В качестве примера приводим запись из метрической книги Греческой Предтенческой церкви г. Керчи, среди поручителей, бракосочетавшихся в 1867 году, находим итальянских подданных Якова и Доменико Фабри. (Запись метрических книг о родившихся, бракосочетающихся и умерших Греческая Предтенческая церковь1866-1871).

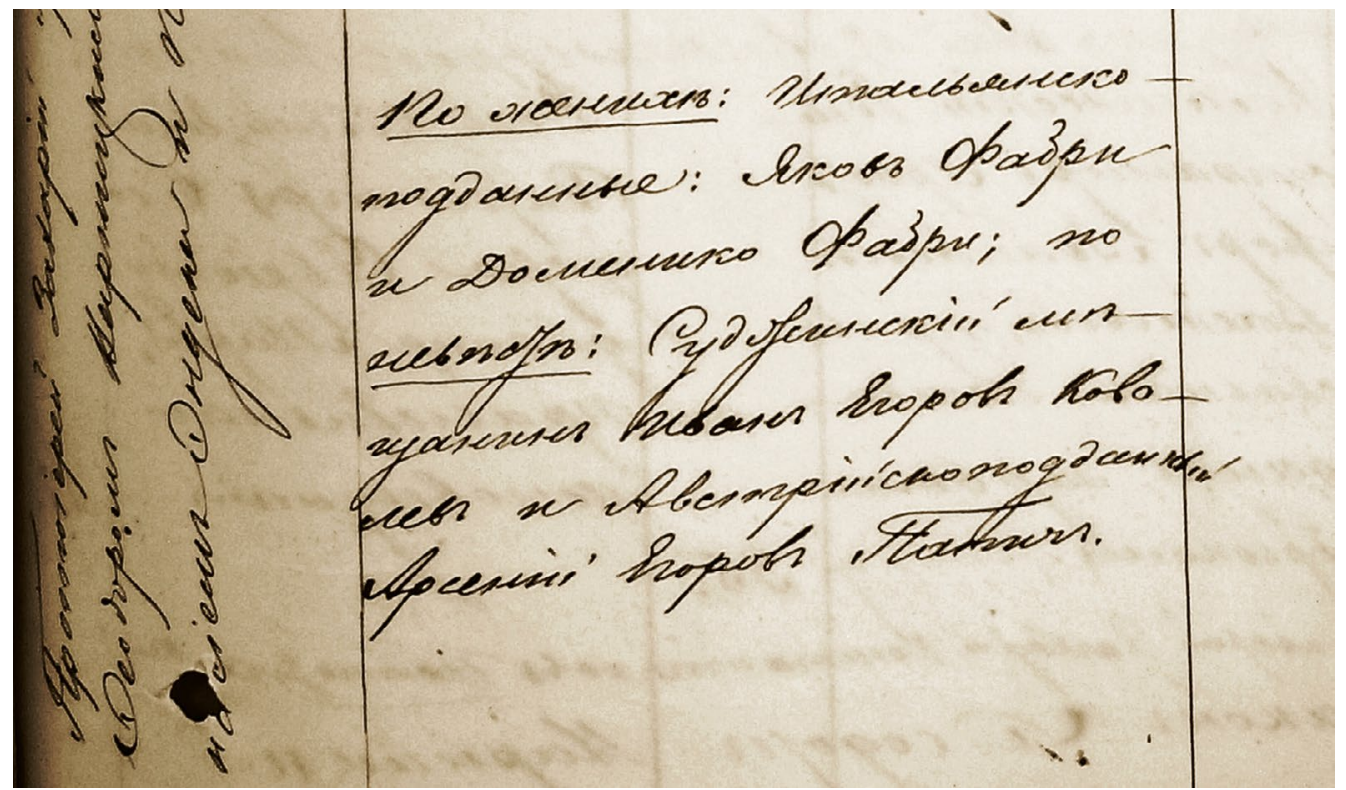

Рис. 9. Фото № 5. Запись из метрической книги Керченской греческой Предтенческой церкви 1866-1871 (ГАРК, г. Симферополь. Ф. 288. Оп. 1. Д. 1). 
В 1850 году Тосканско-подданный Александр Иванович Ванучи с женой регистрируют рождение детей в православном Керченском Троицком Соборе (Запись метрических книг Керченского Троицкого собора 1850), а австрийско-подданный иностранец Петро Коста отмечает рождение сына в 1841 году в Керченской Греческой Предтенческой церкви. (Записи метрической книг о родившихся, бракосочетающихся и умерших Греческая Предтенческая церковь 1831-1842) Важно отметить, что в записях метрических книг указывается вероисповедание человека, если оно отличается от того, исповеданного в данной церкви.

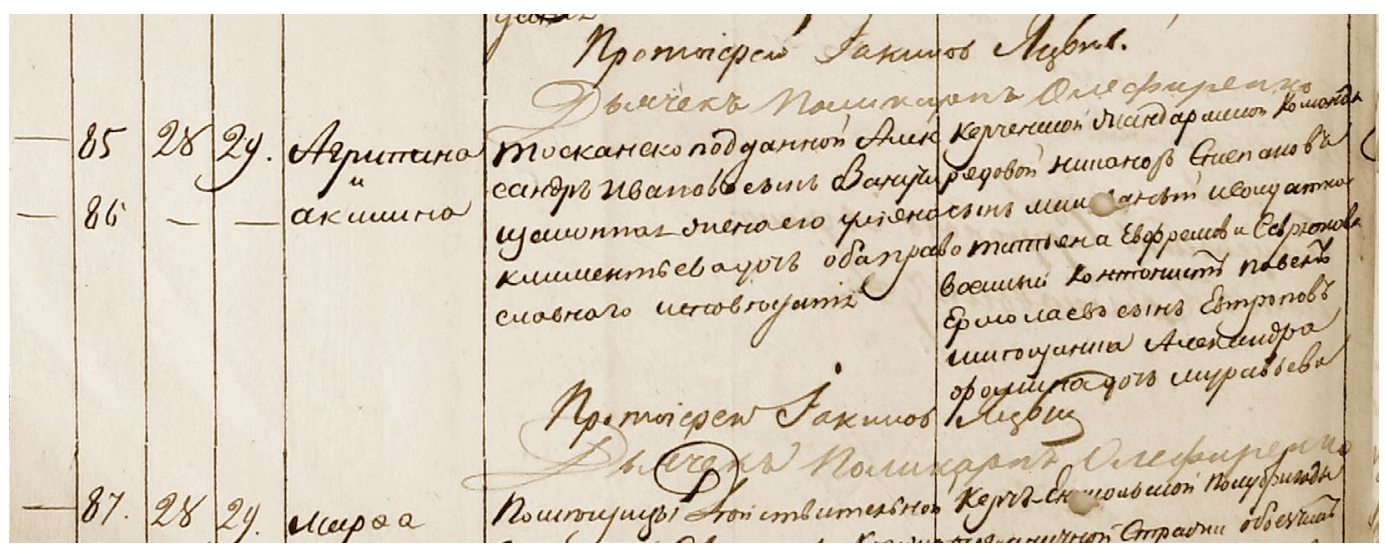

Рис. 10. Фото № 6. Запись из метрической книги Керченского Троичкого собора 1850 (ГАРК, г. Симферополь. Ф. 289. Оп. 1. Д. 6).

Присутствие в Керчи и в других городах Крыма и региона итальянцев, исповедующих православную или иную веру, косвенно оправдывает мнение исследователей об особо заметном присутствии итальянского элемента в Керчи в XIX веке. С другой стороны, изучив записи многих сохранившихся метрических книг керченских и крымских церквей и иных мест богослужения, мы замечаем, что данное явление не носит массового характера.

Другим обстоятельством, встречающимся намного чаще, которое сильно усложняет любую попытку учёта мигрантов, является большое количество граждан не итальянского подданства - преимущественно французского, австрийского, турецкого, греческого - носивших итальянские имена и фамилии, мигрирующих в Крым и в прибрежные города Черного и Азовского моря из Апеннинского полуострова. Не будем углубляться в изучение данного явления, достойного по своим масштабам глубокого, отдельного анализа, так, как наша цель в этом контексте - другая: показать с помощью приведённых выше примеров, наших комментариев и рассуждений, насколько группа итальянских мигрантов, являющихся предметом нашего исследования, была неоднородной, мобильной, трудно определимой по численности, что противоречит понятию обособленности и замкнутости группы.

В списках иностранно-подданных, желающих получить подданство Российской Империи с 1831 по 1914 гг. мы находим представителей 79 государств и национальностей. Из 7160 дел по прощению о принятии в подданство России, мы находим 14 дел Сардинско подданных, 3 Неаполитанско подданных, 7 Тосканско подданных и 77 дел Итальянско подданных (Материалы Архивной инвентаризации. Таврическое Губернское правление - стол иностранно подданных 1831-1914). 


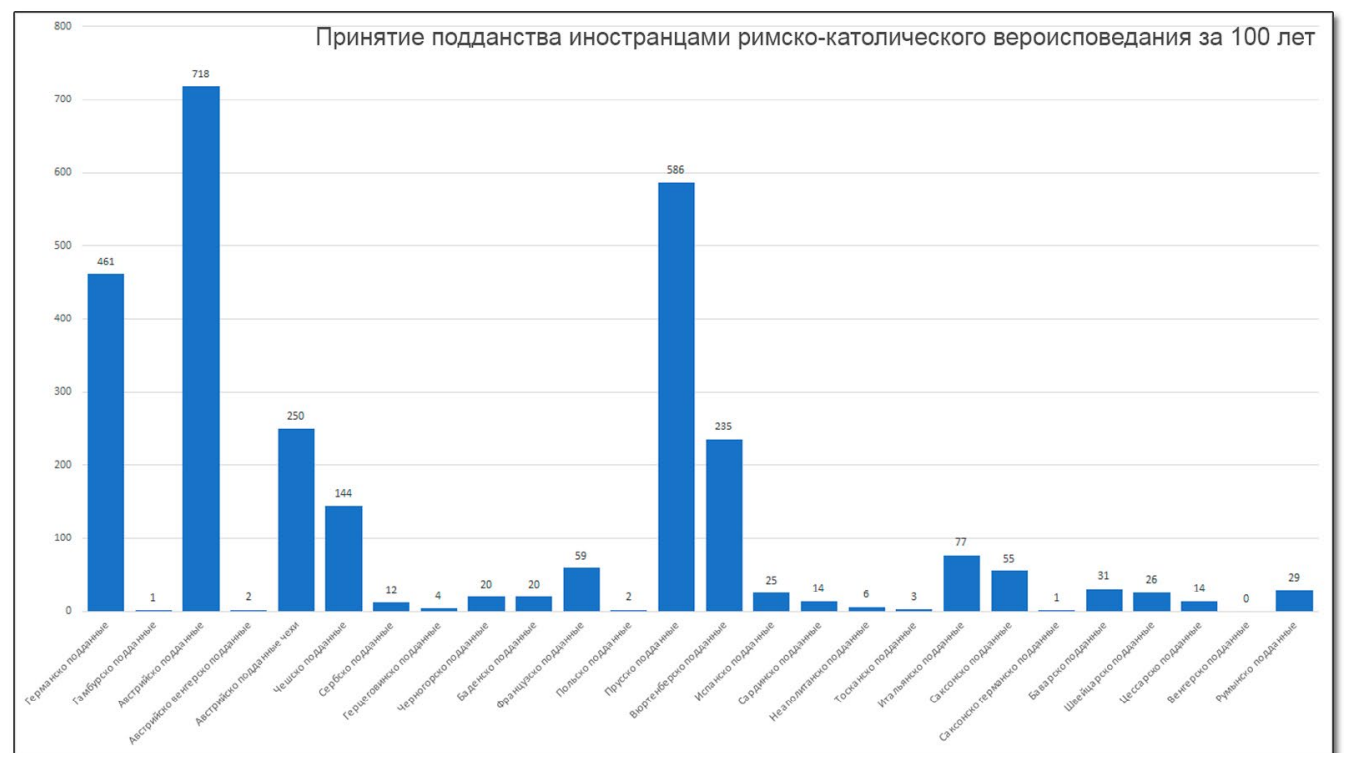

Рис. 11. График № 4. Принятие подданства иностранцами римско-католического вероисповедания за с 1831-1914 г2.

Общее количество уроженцев Апеннинского полуострова составляет 101 человек за период 83 года. Если брать в процентном соотношении от подданных других государств, исповедующих Римско-католическую веру - 2795 дел - то доля итальянского контингента составит 3,61\%. А если брать от общего количества желающих стать гражданами России, то процент уроженцев с Апеннинского полуострова равен $1,41 \%$, что указывает на то, что количество мигрантов с Апеннинского полуострова по сравнению с общим количеством мигрантов незначительно.

Нужно еще отметить, что среди Австрийско, Французско, Турецко подданных, встречаются итальянские фамилии, которые мы не учли. В составлении графика мы придержались к фактическому подданству заявителя.

Начиная с начала XIX века и до начала XX, можно прослеживать разные миграционные волны, направленные с Апеннинского полуострова, в разные годы в разные города Российской Империи всего Черноморско-азовского бассейна. В зависимости от географии переселения и расселения, первую миграционную волну - с дня основания г. Одессы и до 20-30-х годов XIX века - можно условно назвать Одессито-Феодосийской; вторую - Феодосийско-Керческой - с 30-х годов XIX века и до начала Крымской войны; третью - Керченско-Азовской - после окончания Крымской войны и до конца XIX века. Отдельно можно выделить четвертую группу, почти исключительно итальянских полит-мигрантов, прибывших в южные регионы России (Советского Союза) в первые декады XX века.

Переменность миграционных движений - притоки населения в мирные годы чередовались с явными оттоками в военное время - оживлённые перемещения семей мигрантов между городами региона и огромное количество неучтённых постоянно прибывающих и отбывающих мореходцев, делает невозможным проводить чёткую черту между миграционными потоками. 
Подводя итог, мы не соглашаемся с определениями «керченская группа» или «керченская община», и будем называть итальянских мигрантов нашего исследования «крымскими итальянцами» или «итальянцами Крыма», считая эти названия весьма условными и, вкладывая в них совокупное, более широкое человеческое и территориальное понятие «мигрантов с Апеннинского полуострова в Крым и в Черноморско-азовский регион».

Этим, мы не отрицаем, что город Керчь, который в силу своего местоположения стал некой стратегической точкой на карте региона со дня своего появления, занял немаловажное место в истории миграции крымских итальянцев. Даже сегодня именно Керчь играет определяющую роль в жизни и существовании группы. Вероятно, если бы не старания крымской итальянки Джулии Джаккетти, родившейся и проживающей в г. Керчь и немногих других итальянцев Крыма, для которых желание сохранить угасающее эхо предков стало делом жизни, сегодняшние крымские итальянцы вспоминали бы о далёких корнях все реже и реже, до выцветания последней бабушкиной фотографии и полного растворения воспоминаний в повседневном местном быту.

Понятие «Итальянцы Крыма», как жизнеспособная этническая группа - возникло с созданием крымским итальянцем Петром Перголо, в 1992 году, первого общественного объединения этнических итальянцев в Дружковке (Украина). В том же году, в Керчи была учреждена «Ассоциация итальянцев Крыма», а уже в 2008 году Джулия Джаккетти основала «Итальянскую Ассоциацию ЧЕРКИО», которой руководит и по сей день (Джаккетти-Бойко 2016: 16).

Черкио - название ассоциации втройне символическое. Черкио, это старое название города при генуэзском правлении в XIII веке, это также сокращение названия «Сообщество потомков, эмигрировавших в Крым, итальянцев по происхождению» в переводе на итальянском языке (Comunita' degli Emigrati in Regione di Crimea - Italiani di Origine) a, также итальянское слово cerchio, означает по-русски - круг.

Итальянка по материнской линии, Джулия Джаккетти сегодня - двигатель и душа общины. Именно к Джулии мы обратились, в первую очередь, в самом начале нашей исследовательской работы, с первыми естественно возникшими вопросами: кто же, в неспокойном XIX веке, как, откуда и почему мог решиться покинуть тёплый Апеннинский полуостров и отправиться в долгий и рискованный путь в малоизвестном в то время направлении.

Из Юга Италии, в частности из Апулии, безнадёжно бедных земледельцев зазвала в Крым раздача земель на безвозмездной основе, инициированная Императрицей Екатериной II для привлечения иностранных рабочих рук и заселения южных территорий, недавно ставших частью Империи. Примерно так, если очень кратко, прозвучал Джулин ответ, породивший вскоре новые вопросы и вызывавший ряд сомнений, которые оправдались с самого начала нашего исследования, когда мы стали опрашивать представителей крымско-итальянской группы.

И здесь мы возвращаемся к очень интересному факту, так называемым мифам, которые передаются из уст в уста, из поколения в поколения. Как мы видим, этот миф связан с раздачей земель итальянцам Екатериной II.

История последних миграций итальянского населения в Черноморский и Азовский регионы и в Крым начала свой фактически отсчёт в первые декады XIX века, но мы считаем необходимым описать картину главных исторических событий, начиная с середины XVIII века, по трём главным причинам. 
Во-первых, важно уделить внимание некоторым событиям конца XVIII века так, как начало заселения Крыма иностранцами и появление заметного иностранного элемента в городах Черного и Азовского побережий, играющих в дальнейшем значимую роль в динамике миграционных потоков и в развитии отношений между Апеннинским полуостровом и Черноморско-азовского регионом, нужно отнести к этому времени (Зенкевич 1894: 31-40).

Во-вторых, именно в эту эпоху образовались или обрели новый статус многие города связанные, в разной степени и в разное время, с возникновением и развитием изучаемой нами группы. Таганрог был основан в 1698 г., но обрёл статус города в 1775 г., Херсон в 1778 г., Мариуполь, основанный в Х в., стал городом в 1778 г. Николаев возник в 1789 г. и уже в следующем году обрёл статус города. Город Одесса был основан в 1794 г. Среди городов, играющих значимую роль в истории итальянцев Крыма, только Бердянск возник в XIX в. (основан в 1827 г., город с 1835 г.), а старинные города Феодосия и Керчь обрели тогда же вторую жизнь.

Перед тем, как продолжить наш рассказ, важно подчеркнуть, что в связи с колоссальным количеством исторических событий, произошедших в интересующие нас эпохи, мы будем относиться к историческим фактам избирательно, игнорируя все те, которые по временным, географическим или иным причинам отдаляются от предмета нашего исследования и имеют мало к нему отношения.

Нет сомнений, что эпоха Екатерины II - судьбоносный период в истории Крыма и черноморско-аАзовского регионеа Присоединение черноморского и азовского побережий и Крыма к Российской Империи при Екатериной II, привело к коренным изменениям в этническом составе региона, менявшим кардинально и навсегда облик вновь приобретенных территорий. Освоение Россией стратегически столь важного региона провоцирует возникновение новых торговых путей из Старого Света на Восток, а также открывает для Российской империи Средиземное море.

Расширение Российской империей сферы своего влияния и укрепление своего присутствия на берегах Азовского и Черноморского регионов усугубляют вековое противостояние с Османской Империей.

Именно при Екатерине II, то, что раньше можно было назвать физиологическим антагонизмом между двумя державами, принимает форму долгосрочного стратегического плана, который предполагает воссоздание христианской империи со столицей в Константинополе.

Именно при Екатерине II началась систематическая колонизация и массовое заселение Таврической Губернии и Крыма, которые осуществлялись под чутким руководством графа Потемкина, с двумя главными целями.

Во-первых, превращение Тавриды в провинцию, верную Российской Империи, было делом стратегически необходимым для пресечения опасности, постоянно грозившей южным пределам России со стороны Порты (Brikner 1885: 426-440, 640649, 667-689).

Во-вторых, массовые эмиграции крымских татар в Турцию в 1783 году и в последующие годы, вызванные притеснением крымской администрацией и экспроприацией крымских земель у крымскотатарских крестьян, привели к тому, что остались заброшенными не только населённые пункты, но и сады, виноградники и пахотные земли.

Императрица, считая себя главою православной церкви, к вопросу о заселении Крыма относилась, главным образом, с точки зрения религии и первые переселенцы были 
православные - греки, армяне, болгары, албанцы-арнауты и, конечно же - русские.

Были ли итальянцы среди первых переселенцев, вопрос остается открытым.

В трудах историка Писаревского Г.Г. рассказывается примерно о 2000 итальянцев - земледельцев, отправленных в те годы в Херсон, русским генералом, морским комиссаром в Италии, командующим русской эскадрой в Ливорно, графом Дмитрим Мочениго, действующим от имени русского правительства в качестве агента - зазывателя иностранной рабочей силы (Писаревский 2011: 90)

Возникают сомнения в том, были ли эти 2000 человек итальянцами. Они будто бы растворились, не оставив о себе следа ни в одном историческом документе. Безвозмездная раздача земель, инициированная Екатериной II, не была причиной начала миграционных потоков жителей Апеннинского полуострова в черноморско-азовский регионы и в Крым.

Мы делаем вывод, что итальянцы Крыма просто позаимствовали часть своей истории у греков.

Еще один миф: их предки - земледельцы из Юга Италии.

Социально-демографическо-этнографический опрос, проведённый нами среди крымского итальянского населения, предполагающий сбор демографических данных до четвертого поколения, не зафиксировал ни одного воспоминания о предках-земледельцах. Дедушки и прадедушки, о которых остались какие-либо сведения, были мореходцами. Фотопортреты из семейных архивов отображают в основном обеспеченные семьи (Фото № 7). Несколько раз представители старших поколений заставляли нас усомниться в несостоятельности своих предков, вспомнив о семейных состояниях в виде сундучков с золотыми ожерельями бабушек и мешочков с деньгами дедушек.

Проведя анализ фамилий мигрантов, мы отмечаем более $78 \%$ семей северного происхождения, такие, как Тубино, Ботто, Аморетти, Гарибальди, Росси, Васси, Томазини, Лагорио, Скасси и др.

Работа с архивными источниками и с документами из библиотечных фондов подтвердила, что большая часть мигрантов с

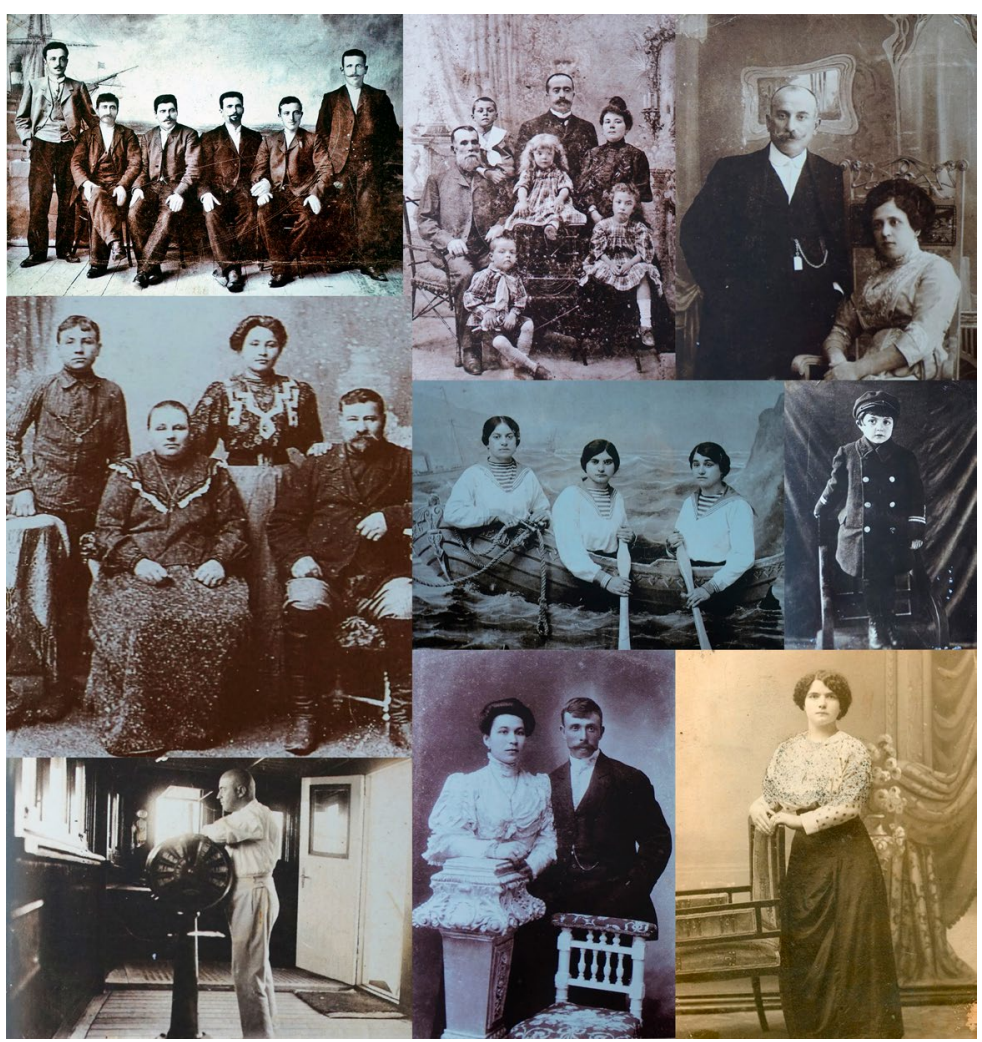

Pис. 12. Фото № 7. Фотографии из личных архивов Крымских итальянцев (Личные архивы ХІХ-ХХ вв.). 
Апеннинского полуострова являлась выходцами из Северных регионов Италии, для которых черноморско-азовский регион представлял исключительно коммерческий интерес. В качестве примера можно привести список из Полицейского листка Керчь-Еникольского градоначальства о приходе заграничных торговых судов в Керченский порт (Полицейский листок Керчь-Еникольского градоначальства № 15 1862). Из этого списка мы видим, что основную часть судов составляют корабли и капитаны из Сардинского королевства (Фото №8). Если брать информацию о навигации в течение года, например за 1858 г., то мы можем привести такие цифры - Сардинские - 221 из них с грузом 23, 198 с балластом, Тосканские - 24, из них 4 с грузом, 20 с балластом, Неаполитанские - 14, из них 3 с грузом 11 с балластом, Папские - 2 .

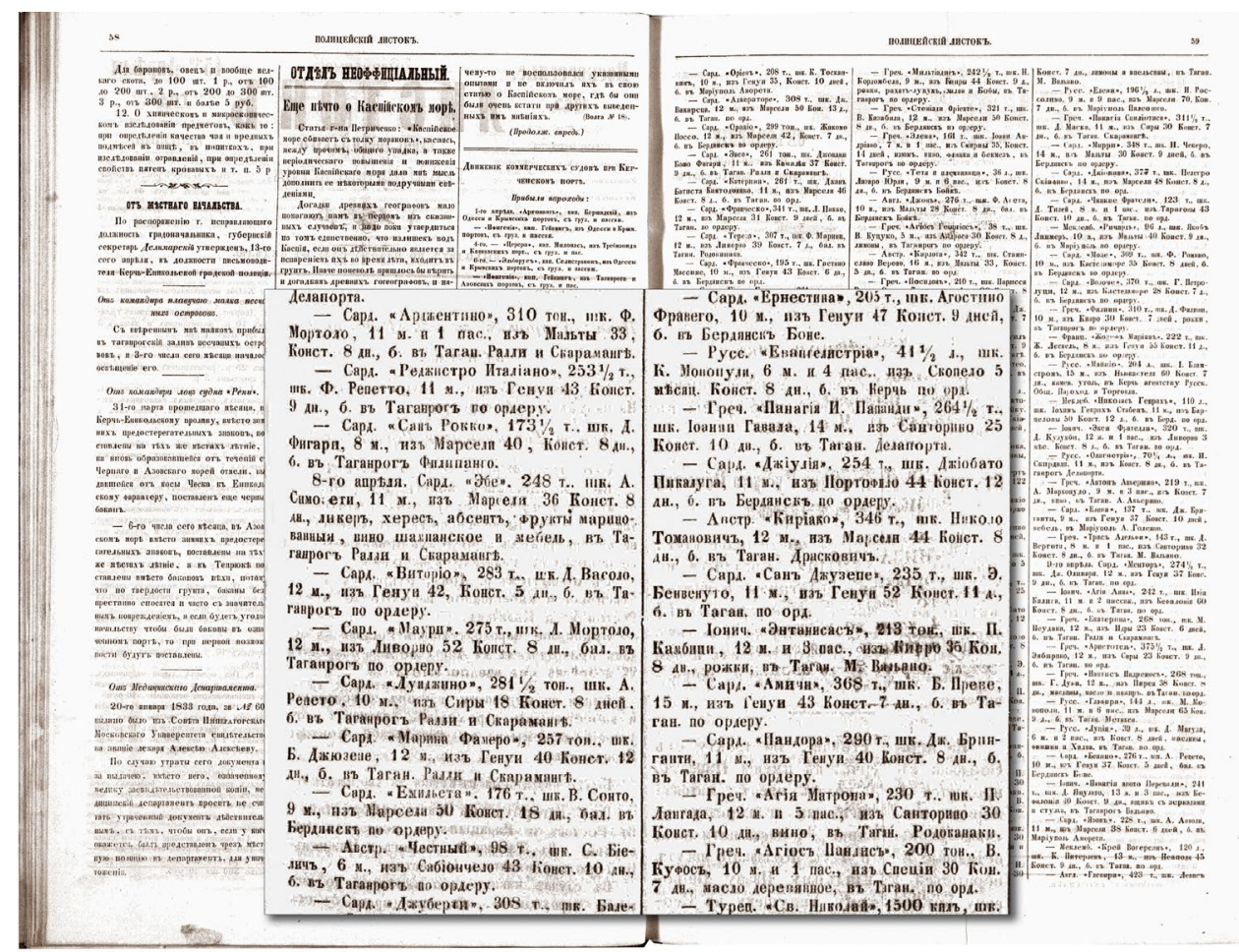

Рис. 13. Фото № 8. Списки судов, капитанов, грузов, портов отбытия и прибытия судов, а также заказчиков груза. Поличейский листок Керчь-Еникольского градоначальства № 15. 15 апреля 1862 г. (Еженедельное издание).

Кто сможет выявить, когда и как возникли эти мифы, которые, переходя из уст в уста, обрели все больше и больше облик правды, раскроет, вероятно, загадки, связанные с историей итальянцев Крыма. Мы пока от этого далеки и изложим те ответы, которые мы нашли, надеясь, что они станут поводом и причиной новых исследований.

В любом случае, есть один неопровержимый факт, из которого нужно исходить. В XIX веке, в разные годы и по разным причинам мигранты с Апеннинского полуострова переселялись в Крым и вдоль Черноморского и Азовского побережий.

Их потомки, проживающие сегодня в основном в Керчи и в других городах Крыма, России, Италии, мира, составляют единую группу индивидов, не всегда между собой дружных и едино мыслящих, но объединенных сильным желанием не забыть, сохранить и дальше защищать свою исходную культурную и этническую идентичность. 


\section{Источники и материалы}

Записи метрических книг о родившихся, бракосочетающихся и умерших 1866-1871, Греческая Предтенческая церковь г. Керчь: фонд 288, оп .1, ед.хр. 7. Государственный архив Республики Крым, г. Симферополь.

Записи метрических книг Керченского Троицкого собора 1850. Ф289. Оп1. Ед.х.6 Государственный архив Республики Крым, г. Симферополь.

Записи метрической книг о родившихся, бракосочетающихся и умерших 1831-1842 Греческая Предтенческая церковь г. Керчь: фонд 288, оп. 1, ед.хр. 2 Государственный архив Республики Крым, г. Симферополь.

Записи метрических книг римско-католических церквей херсонского деканата о родившихся в 1834-1836 гг. Государственный архив Саратовской области ГАСО г. Саратов: фонд 1166, оп. 63 , ед.хр. 68.

Записи из метрических книг о родившихся, бракосочетающихся и умерших 1866-1871. Греческая Предтенческая церковь г. Керчь - Фонд 288 оп.1 ед.хр.7 Государственный архив Республики Крым, г. Симферополь.

Записи из метрических книг Керченского Троицкого собора 1850г. Ф289. Оп1. Ед.х.6 Государственный архив Республики Крым, г. Симферополь.

Записи из метрических книг о родившихся, бракосочетающихся и умерших 1831-1842 Греческая Предтенческая церковь г. Керчь Фонд 288 оп.1 ед.хр.2 Государственный архив Республики Крым, г. Симферополь.

Итоги переписи населения в Крымском Федеральном округе, официальное издание. Федеральная служба государственной статистики ИИЦ «Статистика России». Москва, 2015. C. 143.

Материалы из личных архивов Джулии Джаккетти-Бойко (г. Керчь) и Петра Пергало (г. Санкт-Петербург).

Материалы Архивной инвентаризации опись №7 дел фонда №27 «Таврическое Губернское правление» стол иностранно подданных 1831-1914 Тома №1-2-3 Государственный архив Республики Крым. г. Симферополь.

Российский государственный военный архив РГВА г. Москва. Фонд 730К. Оп.1. Дело 229. Список членов Феодосийской масонской ложи Иордана. 1812. С. 94-95.

Указ Президента Российской Федерации О мерах по реабилитации армянского, болгарского, греческого, итальянского, крымско-татарского и немецкого народов и государственной поддержке их возрождения и развития (В редакции Указа Президента Российской Федерации от 12.09.2015 г. N 458). Доступ: http://kremlin.ru /acts/bank/38356 28.05.2019.

Фотоматериалы из личных архивов Крымских итальянцев XIX-XX вв.

\section{Научная литература}

Брикнер 1885 - Брикнер А. История Екатерины Второй Том2. Санкт-Петербург: Типография А.С. Суворина, 1885. С. 426-440, 640-649, 667-689.

Джаккетти-Бойко 2016 - Джаккетти-Бойко Д.Е. Итальянцы Крыма. История и судьбы. Симферополь: «Бизнес-инфо», 2016. С. 7-16 .

Зенкевич 1894 - Зенкевич Хр.Хр. Керчь во прошедшем и настоящем - историко-археологический и географический очерк. Керчь: Скоропечатная типолитография Х.Н. Лаго и К.Б Холева, 1894. С. 31-40.

Керченский статистический комитет 1860 - Керченский статистический комитет. Памятная книжка Керчь-Еникольского Градоначальства. Керчь: Издание Керченского статистического комитета, Типография И. Холева, 1860. С. 67-70.

Керченский статистический комитет 1865 - Керченский статистический комитет. Памятная книжка Керчь-Еникольского Градоначальства. Керчь: Издание Керченского статистического комитета, Типография И. Холева, 1865. С. 15-20. 
Керченский статистический комитет 1900 - Керченский статистический комитет. Памятная книжка Керчь-Еникальского Градоначальства. Керчь: Издание статистического комитета, 1900. С. 56.

Керченский статистический комитет 1906 - Керченский статистический комитет. Памятная книжка Керчь-Еникольского Градоначальства. Керчь: Издание Керченского статистического комитета, Типография Х. Н. Лаго, 1906. 12 с.

Керчь-Еникольское градоначальство 1862 - Керчь-Еникольское градоначальство Полицейский листок Керчь-Еникольского градоначальства №15. Керчь: Еженедельное издание Керчь-Еникольского градоначальства, 1862.

Писаревский 2011 - Писаревский Г.Г. Избранные произведения по истории иностранной колонизачии в России. Москва: Международный союз немецкой культуры, 2011. 90 с.

Таврический губернский 1900 - Таврический губернский статистический комитет. Памятная Книжка по Таврической губернии. Симферополь: Издание Таврического губернского статистического комитета, $1900.179 \mathrm{c}$.

Федеральная служба 2015 - Федеральная служба государственной статистики ИИЦ Статистика России. Москва: Федеральная служба государственной статистики ИИЦ официальное издание, 2015. $143 \mathrm{c.}$

Шишмарев 1975 - Шишмарев В. Ф. Романские поселения на юге России. Москва: Издательство Наука, Научное Наследие. Академия Наук СССР. Труды архива, 1975. Вып. 26. 165 с.

\section{References}

Brikner A. 1885. Istoriya Ekateriny Vtoroi [History of Catherine the Second]. Pp. St. Petersburg: AS Printing House Suvorin 2: 426-440, 640-649, 667-689.

Giacchetti-Boyko G.E. 2016. Ital'yantsy Kryma. Istoriya i sud'by. [Italians of Crimea. History and fates]. Simferopol: Business-Info. Pp. 7-16.

Zenkevich Khr. Khr. 1894. Kerch' vo proshedshem i nastoyashchem - istoriko-arkheologicheskii i geograficheskii ocherK. [Kerch in the past and present - historical, archaeological and geographical essay]. Kerch: Skoropressnaya Tipo-lithography H.N. Lago and K. (B. Holeva). Pp. 31-40.

Kerchenskii statisticheskii komitet. 1860. Pamyatnaya knizhka Kerch'-Enikol'skogo Gradonachal'stva [Kerch Statistical Committee. 1860. Memorial book of the Kerch-Yenikolsky Town Administration]. 21: 67-70.

Kerchenskii statisticheskii komitet. 1865. Pamyatnaya knizhka Kerch'-Enikol'skogo Gradonachal'stva [Kerch Statistical Committee. 1865. Memorial book of the Kerch-Yenikolsky Town Administration]. Kerch: Publishing of the Kerch Statistical Committee, I. Kholev Printing House. Pp. 15-20

Kerchenskii statisticheskii komitet. 1900 Pamyatnaya knizhka Kerch'-Enikol'skogo Gradonachal'stva. [Kerch Statistical Committee 1900. Memorial book of the Kerch-Yenikolsky Town Administration]. Kerch: Publishing House of the Kerch Statistical Committee, Kh. N. Lago Printing House. 56 p.

Tavricheskii gubernskii statisticheskii komiteta. 1900. Pamyatnaya Knizhka po Tavricheskoi gubernii. [Tauride Gubernia Statistical Committee. 1900. Commemorative Book for Tauride Province]. Simferopol: Publication of the Tavrichesky Provincial Statistical Committee. 56 p.

Kerchenskii statisticheskii komitet. 1906. Pamyatnaya knizhka Kerch'-Enikol'skogo Gradonachal'stva. [Kerch Statistical Committee 1906. Memorial book of the Kerch-Yenikolsky Town Administration]. Kerch: Publishing of the Kerch Statistical Committee, Kh. N. Lago Printing House. $12 \mathrm{p}$.

Pisarevsky G.G. 2011. Izbrannye proizvedeniya po istorii inostrannoi kolonizatsii v RossiI. [Selected works on the history of foreign colonization in Russia]. Moscow: International Union of German Culture. 90 p.

Kerch'-Enikol'skogo gradonachal'stvo. 1862. Politseiskii listok Kerch'-Enikol'skogo gra- 
donachal'stva No. 15. [Kerch-Yenikolsky Township Police. 1862. Leaflet of Kerch-Yenikolsk Township No. 15]. Kerch: The weekly edition of the Kerch-Yenikolsky town council leaflet.

Shishmarev V.F. 1975. Romanskie poseleniya na yuge Rossii. [Romance settlements in the south of Russia]. Moscow: Science, Scientific Heritage Publishing House. USSR Academy of Sciences. Archived Works. Issue 26: $165 \mathrm{p}$.

Federal'naya sluzhba gosudarstvennoi statistiki. IITS Statistika Rossii. [Federal State Statistics 2015. Service. IIC Statistics of Russia]. Moscow: Federal State Statistics Service. IIC official publication. $143 \mathrm{p}$.

\section{S. Zini, N.V. Khokhlov. The Migration Flows from the Italian Peninsula to Crimea (end of XVIII - beginning of XX centuries). A Historical Sketch - Part 1}

The article is dedicated to the history of the Italians of Crimea. The history of the group is still little studied and rich in myths and legends. Our complex historical-anthropological and genetic study of the community allowed us to dispel some myths, which are widespread among the members of the community and far beyond it, and to recreate the history, geography and causes of migrations that took place in the XIX century. The historical part of the research was mainly based on sources and documents found in the Russian and Italian archives. We used documents from the State Archive of the Saratov Region, the State Archive of the Republic of Crimea, the Russian State Military Archive of Moscow, the state archives of Genova, Napoli, Bari, Turin, and the Vatican Secret Archive. Extensive and equally useful information was found in newspapers and other periodicals of the XIX-XX centuries from Russian and Italian library collections. Family archives of descendants of Italian migrants also provided valuable information. The article presents some of the materials found in the course of the study.

The article also deals with the problem of the size of the community, which is difficult to define both today and in the past.

Key words: migration flows, migrants, historical essay, field research, Crimean Italians, Kerch, Apennine Peninsula, Italy, Crimea 